Historic, Archive Document

Do not assume content reflects current scientific knowledge, policies, or practices. 


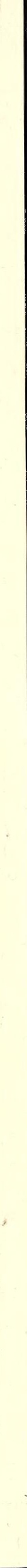




\section{SPECIAL FALL PRICE LIST, 1931}

\section{BOYD NURSERY COMPANY}

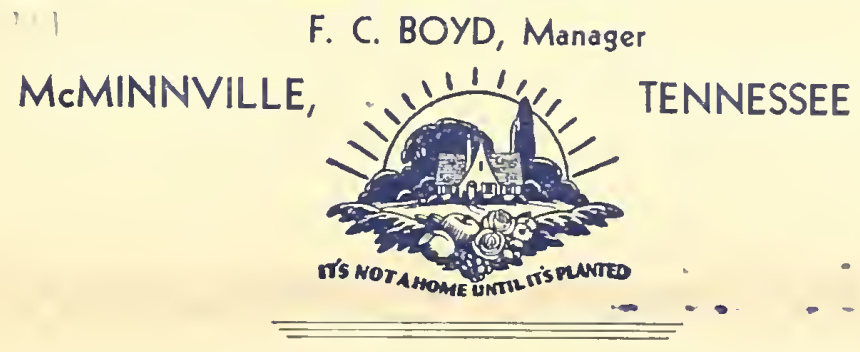

FALL PLANTING

Fall planting of shrubs, trees and flowers has an advantage over spring planting in that all during the long winter months the root systems are forming and no damage may be done from drouth or heat, which all too often follow spring planting before the transplanted shrubs have sufficient opportunity to take ample root in their new location. You may expect better plants next summer, better growth and less loss by anticipating your spring needs, sending in your order now and getting the plants in the ground this fall. Orders received prior to fall shipping time will be filled just as soon as it is safe to move the plants.

Realizing that many of our customers have had a difficult business year, we have made our fall prices lower than ever before. Our price list has been scaled down to fit your pocketbook. You have no need to feel that you cannot afford to do some planting on account of the cost. We do not believe that you will ever be able to plant so reasonably as now. Read the list below carefully and be convinced.

It is easy to order by mail. Just fill in the enclosed order blank, being particular to specify just what is wanted. Your name, post office and shipping point should be written plainly to avoid mistakes.

These prices are F.O.B. McMinnville. No charge for packing.

The only way to relieve the business depression is to spend a little money regularly. Such a policy will enable everyone to start buying, and quickly bring back good business. Put something into flowers and shrubs this fall. Even though you cannot buy all you want, add something to the value of your home now by planting at least a few shrubs or trees.

\section{FRUITS FOR THE HOME}

Ornamental Plants are our specialties; yet we sell a line of the most popular fruits for the Home Garden, covering the entire season. Every home should have plenty of nice, fresh "Home Grown" Fruit. It is an asset to good health, as well as a source of saving on the food bill. Fruit Trees add beauty, as well as being producers of delicious food.

There are perhaps more Peach and Apple trees produced in Warren County than any other county in the state, and our orders are filled from the nurseries of men whom we believe to be reliable and trustworthy growers, who grow and sell only sound, healthy stock, prolific in fruiting and growing quality, true to name, thereby insuring success in your orchard and garden operation. Place your order now, and plant your trees in the fall, thereby getting the benefit of the early spring growing season.

\section{APPLE TREES AT REDUCED PRICES}

Early Harvest. Medium to large, bright yellow. Horse. Large, green, acid. Good for cooking and drying. Red June. Deep red skin, tender and juicy. Jonathan, striped red. Good quality.

Kinnard's Choice. Is good for market or table.

King Davis. A beautiful apple. Tree strong grower.

Maiden Blush, pale yellow. Good for cooking.

Wealthy. Strong tree. Some regard this variety finest that grows.

Arkansas Black. Mammoth Black Twig.

Delicious, red. Fruit of uniform size.

Delicious, red. Fruit of uniform size.
Baldwin. Fruit good for cooking or eating.
Ben Davis. Large and round. Red striped.

Ben Davis. Large and round.
Gano. An apple butter kind.

Northwest Greening. Fruit medium to large.

Rome Beauty. A good quality.

Rome Beauty. A good quality.

Winesap. Trees hardy, and early constant bearer.

York Imperial. White shaded. One of the best winter apples. Yellow Transparent. Fruit large yellow.

Prices on one-year whips:

18 to 24 inch, 1 -year whips

3 to 4 feet, 1 -year whips. Per 10 Per 100

$1.30 \quad 10.50$

The following prices are for strong, two-year trees:

$\begin{array}{lrrr}3 \text { to } 4 \mathrm{ft} ., & 7 / 16 \text { in. caliper....... Each } & \text { Per } 10 & \text { Per } 100 \\ 4 \text { to } 5 \mathrm{ft}, \mathrm{25} & 9 / 16 \text { in. to } 11 / 16 \mathrm{in} . & \$ 1.90 & \$ 15.00\end{array}$

4 to $5 \mathrm{ft} ., 9 / 16$ in. to $11 / 16$ in.

$2.65 \quad 22.50$

\section{PEACH TREES}

Belle of Georgia. A medium season peach

Crawford's Early: Large, with yellow skin and yellow flesh.

Early Elberta. Ripens earlier than the Elberta.

Elberta. A large yellow peach shaded with red. Very dependable.

Heath Cling. Very large. Ripens early in September.

Hiley. Early, large, creamy white.

J. H. Hale. Mid-season peach. Large and round.

Krummel. A freestone peach, ripening in late September.

Carmen. Early, large. A very hardy and good all, round peach.
Champion. Free. Early, ripens last of July.

Mayflower. One of the earliest peaches. Red all over.

Rochester. Early, prolific, very hardy. Large fruit.

Prices all varieties of peaches: Each Per 10 Per 100 2 to 3 feet................. $.15 \quad \$ 1.30 \quad \$ 11.25$ 3 to 4 feet..................... $.25 \quad 15 \%$ 4 to 5 feet........................ $30 \quad 250.65$

Prices, one-year trees:

18 to 24 inch, June bud.

2 to 3 feet, June bud.

2 to 3 feet, one-year.

CHERRY TREES

Early Richmond. Very early sour cherry. Bright red.

Montmoreney. Well-known, hardy sour cherry. Bright red fruit

May Duke. Medium, dark red. Fine for preserving. Nearly sweet.

Black Tartarian. A favorite sweet cherry. Large, dark fruit,

Napoleon. An ideal, light colored sweet cherry.

Goveruor Wood. One of the best sweet cherries. Large, light red, juicy and delicious.

Prices, all varieties of Cherry Trees:

\begin{tabular}{|c|c|c|c|}
\hline 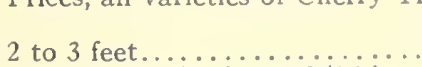 & $\begin{array}{l}\text { Each } \\
\$ .30\end{array}$ & $\begin{array}{l}\text { Per } 10 \\
\$ 2.65\end{array}$ & $\begin{array}{l}\text { Per } 100 \\
\$ 18.75\end{array}$ \\
\hline 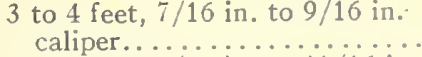 & .50 & 4.15 & 33.75 \\
\hline 5 feet, $9 / 16$ in. to $11 / 16$ in. & & 4.90 & \\
\hline
\end{tabular}

PEAR TREES

Bartlett. A great favorite. Golden yellow with red cheek.

Bartlett. A great favorite. Golden yellow

Garber. Fruit large, Fine for canning and cooking.

Pineapple. Strong, vigorous grower.

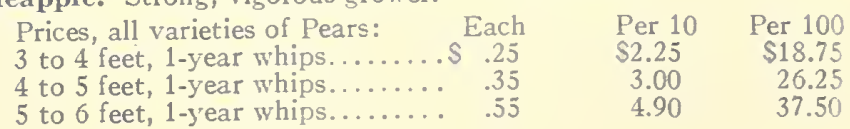




\section{PLUMS}

Abundanee. One of the largest and hardiest. Burbank. Large, deep red, with yellow flesh.

Red June. Tree large and vigorous growing. Fruit very sweet.

Kelsey's Japan. Large, greenish yellow, sometimes flushed with red. Wild Goose. Bright red, juicy, sweet. Cling.

Prices, all varieties of Plums:

2 to 3 feet.

3 to 4 feet.

\section{GRAPES}

BLACK VARIETIES-Moore's Early, Campbell's Early, Con-

WIIITE VARIETIES-Niagara, Poeklington, Martha.

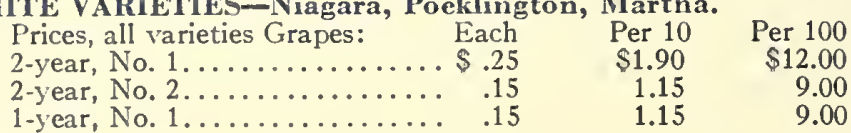

\section{BLACKBERRIES}

Early IIarvest. Earliest to ripen, medium size, good quality.

Snyder. Hardy, fruit early, medium sweet, good size.
Prices all varieties Blackberries:
Per 10
Per 100
Good strong plants.

\section{RASPBERRIES}

Cumberland. Black, very hardy. Early, firm, good size berries. Gregg. Black, few seeds. Berries large, firm. Ship well.

St. Regis. Everbearing red. Large, sweet berries of attractive red, producing a good crop in July and continues to fruit all summer. Very profitable, as the late berries command high prices. 8c each. $65 \mathrm{c}$ per $10 ; \$ 5.00$ per 100 .

Latham. A new red raspberry, hardy, productive, excellent for garden planting. $15 \mathrm{c}$ each; $\$ 1.40$ per $10 ; \$ 8.25$ per 100 .

Prices, all varieties except St. Regis and Latham: Good strong plants................ Per 10

Per 100

Common Wild Blackcap. Purplish black skin Ripens late in season.

RED VARIETIES-Brighton, Catawba, Delaware, Lutie. cord, Worden.

Eldorado. Very hardy, extra fine quality. Hardy in North.

\section{STRA WBERRIES}

Aroma. Steady producer. Berries of excellent eating quality. Champion. A late and heavy bearer of good size berries. Gandy. Fruit firm and of good quality. Excellent for canning. Klondike. Fine flavor, neither sweet nor sour.

Senator Dunlap. Fruit very large, mid-season.

Progressive Everbearing. Berries similar to Dunlap, very productive. Prices on above varieties; $\$ 0.75$ per $100 ; \$ 3.00$ per $500 ; \$ 5.00$ per 1000 .

\section{APRICOTS}

Moorpark. Fruit small, pale orange, trees hardy and productive.

Royal. Extensively planted, desirable for canning and drying.

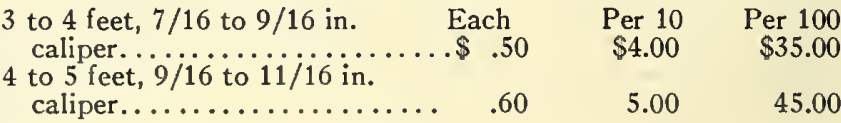

\section{FIGS}

Brown Turkey. A unique combination of delicious flavor.

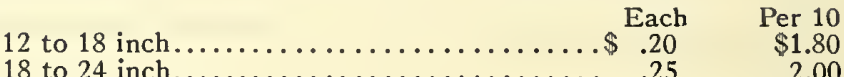

RHUBARB ROOTS

Pie Plant. Recommended for home or market.

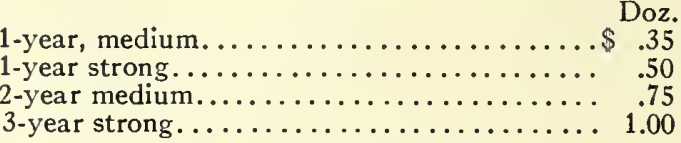

\section{ASPARAGUS}

Palmetto. One of the best. Favorite in the South.

Washington. A new variety, tips tight and firm, stalks large and tender.

1 -year roots. Doz. 100

2-year roots 3.00

\section{ENJOY THE BEAUTY OF FLOWERING SHRUBS}

Beautify your home grounds and give that home-like, permanent appearance in place of a stark, bare house. "It's not a home until it's planted." Just a little shrubbery adds a touch of beauty. By carefully selecting different varieties of shrubs, a succession of bloom may be had throughout the season. Many people do not realize at how small a cost the home may be made a center of beauty. ARONIA, Chokeberry. Attractive, perfectly hardy shrubs. Pale green
foliage, coloring to vivid red in the fall. Inconspicuous white flowers, followed by lasting berry-like fruits. We can furnish two varieties: one with red berries-Arbutifolia, and the other with blackberriesMelanocarpa.

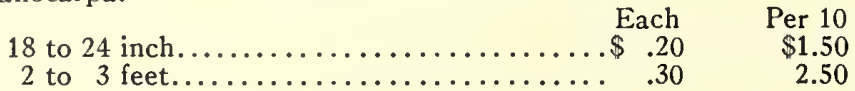

MALLOW MARVELS. A wonderful perennial Hibiscus growing from 4 to 7 feet, and in a clump several feet around, loaded with mass of

One-year transplanted, mixed colors....... .10 $\quad .90$

Two-year transplanted, assorted colors .......... .15

ARALIA PENTAPHYLLA. Long, slender, gracefully arching branches and bright green, compound foliage. Makes a small tree in time, especially attractive on rocky slopes. Greenish white flowers. Does well in shady places.

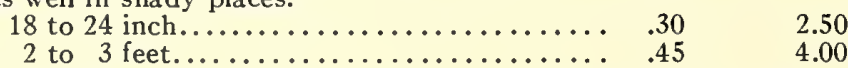

BUDDLEIA, Butterfly Bush. Blooms continually from June unti frost, blue lilac-like flowers which are very fragrant and attract swarms of butterflies.

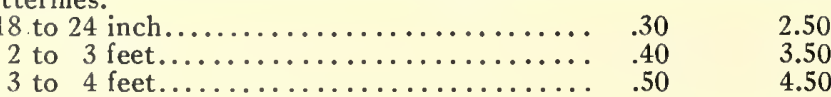
CALLICARPA AMERICANA, Beautyberry. Valuable for its lovely
purple berries borne along the branches in clusters. Handsome in early fall and winter. Grows 3 to 6 feet tall.

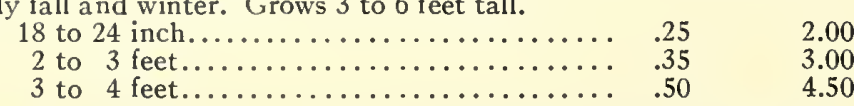

CEPIIALANTHUS, Button Bush. A hardy shrub with large, gloss foliage and attractive creamy white, fragrant flowers appearing in mid-sumner. Valuable for waterside plantings.

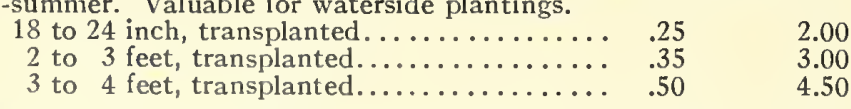

COMPTONIA ASPLENIFOLIA, Sweet Fern. A low shrub with fernlike foliage. Well adapted for massing on rocky banks and sandy stretches.

$$
\begin{aligned}
& 12 \text { to } 18 \text { inch } \\
& 18 \text { to } 24 \text { inch }
\end{aligned}
$$

CRAPE MYRTLE, Lagerstroemia. A beautiful shrub, blooms in August, flowers daintily fringed and borne in immense panicles. We have the crimson and pink.

$$
\begin{aligned}
& 12 \text { to } 18 \text { inch } \\
& 18 \text { to } 24 \text { inch }
\end{aligned}
$$

LDER, Sambucus Canadensis American Elder. Immense topped cymes of white flowers in early summer, followed in early fall by luscious black fruits.

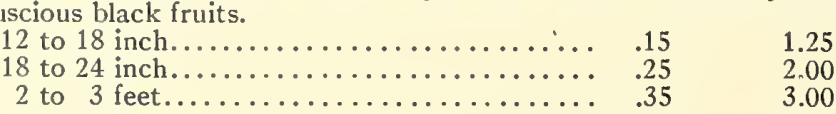

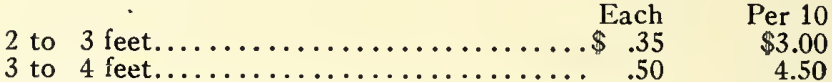

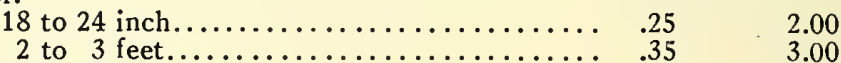

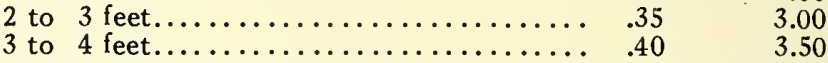

EUONYMUS ALATUS, Cork-Barked Euonymus. Very attractive in autumn when full of bright colored fruit and brilliant crimson foliage. Bark very corky.

18 to 24 inch.....

2 to 24 inch.

3.50 shrub cealed erect in growth, leaves bright green, with rich pink fruits concaled in scarlet pods. Hardy in the North.

18 to 24 inch

$.15 \quad 1.25$

2 to 3 feet.

2.50

LINDERA BENZOIN, Aestivalis, Spice Bush. A very early blooming shrub. The small yellow flowers are followed by scarlet berries. Splendid shrub for mass effect.

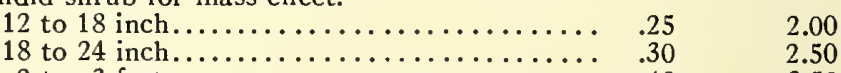

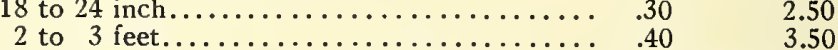

MALUS, Betchel's Flowering Crab. A sturdy grower, flowers large, double, resembling double pink roses, very fragrant. Will bloom when quite young.

2 to 3 feet......................... $.80 \quad 7.50$

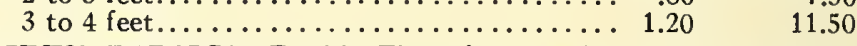

PRUNUS PERSICA, Double Flowering Peach. Can supply red, white and pink. Covered with a mass of beautifully formed and highly colored flowers during March.

2 to 3 feet....................... 7.80

RUNUS PISSAIRDI, Purple Leaf Plum. A very handsome small

tree. Foliage purple, bluish pink flowers in spring.

2 to 3 feet................................ 40

3 to 4 feet...................... 65 . 65

PRUNUS TRILOBA, Double Flowering Plum. A very desirable, 2 to 3 feet............................ 65.00

ROBINIA, Moss Locust. A dwarf bush that sprawls upon the ground. Very showy, with good leaves and rose-colored or lavender-colored Very showy, with good leaves and rose-col
lowers that hang in clusters like wisteria.

18 to 24 inch............................ .25 fowers, but its great attraction are the large, milk-white berries that orm after the flowers drop, and last into mid-winter.

18 to 24 inch............................... 25 summer is covered with clouds of small, pink flowers. We offer two varieties, Africana which blooms in early summer, and Odessana that blooms in late summer

18 to 24 inch.......................... .20
LACINIATA, Cut Leaf Elder. Leaves very finely cut, a very distinct and unusual shrub. In some respects similar to the Golden early flowering shrub, bearing double flowers of a delicate pink shade.

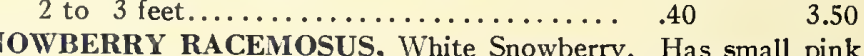
TAMARIX. Foliage is light and feathery as asparagus, and in the 


\section{PLANT EVERGREENS FOR ALL YEAR 'ROUND BEAUTY}

There is nothing that can quite take the place of Evergreens. In the summer their stately grandeur adds serenity to the riot of colors in other vegetation, and in the snowy winter their cheerful freshness gives us the comforting promise, in the bleak landscape, that spring will come again. They can be used in foundation or corner plantings, as single specimens on the lawn or along the driveway, as hedges, windbreaks, and in many other delightful ways.

ABIES BALSAMEA, Balsam Fir. A slender growing tree, of great with cones of a purplish violet color.

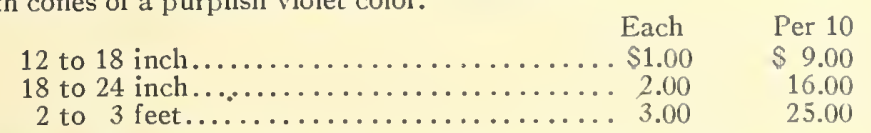

JUNIPER PFITZERIANA, Pfitzer's Juniper. One of our most popular Junipers, used largely in foundation planting. Its light
12 to 18 inch spread
$1.80 \quad 16.00$
18 to 24 inch spread.
35.00

COMMUNIS HIBERNICA, Irish Juniper. Very erect and columnar with dense, silvery green foliage, and upright branches. A few of these can be planted to advantage in almost every lawn.
18 to 24 inch
.80
7.20
30 to 36 inch
1.60
14.00

RGINIANA, Red Cedar. A very hardy, pyramidal-shaped evergreen tree, or one that can be trimmed to any desired shape. Ligh green foliage, which becomes darker as the season advances. A rapid grower.

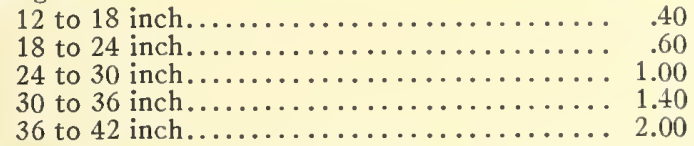

36 to 42 inch.

1.40

EXCELSA PICEA, Norway Spruce. Symmetrical in form, of rapid growth. Hardy. Makes a beautiful ornament for the lawn when planted single, and when set out as a hedge or windbreak cannot be beaten.

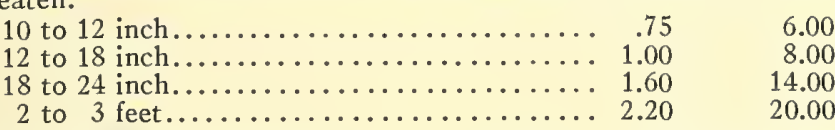

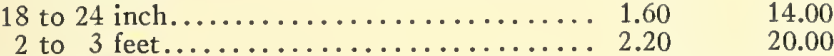

RETINOSPORA PLUMOSA, Green Retinospora. Densely conical, with fern-like leaves of bright green, carried on erect, plumy branches,

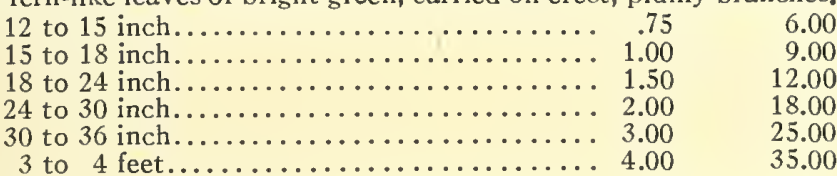

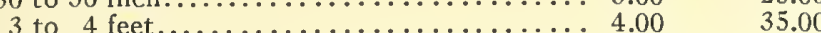

SOUARROSA VEITCHI, Veitch's Silver Cypress. Dense, rounded bubbling growth; the silvery blue foliage arranged in soft spirals which give the impression of boiling over.

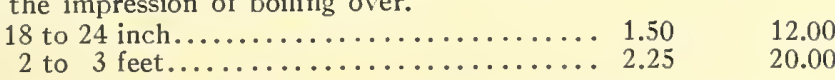

AMIERICAN ARBOR VITAE, Occidentalis. One of our most popular evergreens, because of its easiness to transplant. It thrives under most any condition; can be used as a specimen plant, and is fast becoming popular as a hedge plant.

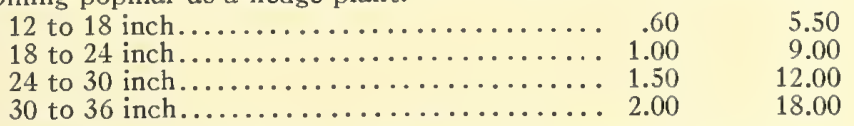

HINESE ARBOR VITAE, Orientalis. Very similar to the AmeriCHINESE ARBOR can, a little more compact; has dark green foliage
singly or in groups. Stands trimming very well.

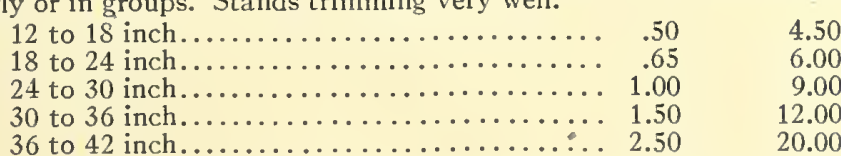

BERCKMAN'S GOLDEN ARBOR YITAE, Aurea Nana. Of dense compact form, golden color. Always beautiful, whether planted alone, in pairs, or on the edge of a group of evergreens.

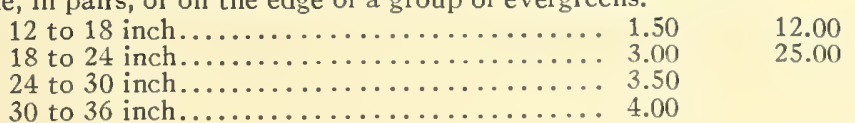

\section{ROSES-A SELECTION OF BEAUTIFUL, HARDY, FIELD-GROWN VARIETIES}

The happiness of mankind may be increased by encouraging that love of a garden, that love of the beautiful which is innate in us all, and in the development of the garden no plant is more worthy of a large place than the ROSE. In what wonderful shades and coloring, in what exquisite variety of form and habit, with what delicate perfume it is now possible to have them! For length of blooming period they have few equals, and no superiors among flowering shrubs-the ROSE stands in a class by itself-THE QUEEN OF FLOWERS.

Prices: Any of the following 2-year-old field grown Roses 50c each; $\$ 4.50$ per ten plants. One-year-old plants $40 \mathrm{c}$ each; $\$ 3.50$ per 10 .

RADIANCE PINK. This rose stands high among growers, because of its vigorous growth, hardiness and continuous production of lovely, light silvery pink, double flowers.

RADIANCE RED. As good as its parent Radiance, in habit of blossom and growth, lovely, deep red, with an intense fragrance.

DAME EDITH HELEN. Shapely buds and substantial, clear pink blooms. Sweetly scented and freely produced on long, strong stems. MRS. CHARLES BELL. Similar in habit to Radiance, of which it is a sport. Color: a lovely shell-pink with salmon shadings. Splendid is a spor
buds. hardy. Foliage lively green, somewhat lighter in color than th Pyramidalis.

$$
24 \text { to } 30 \text { inch. }
$$

36 to 42 inch.

PYRAMIDALIS, Pyramidal Arbor Vitae. Strong, erect, pyramidshaped, densely branched, with rich, dark green, glossy foliage. One
of the best for specimen planting or for striking effect when planted as center of groups.

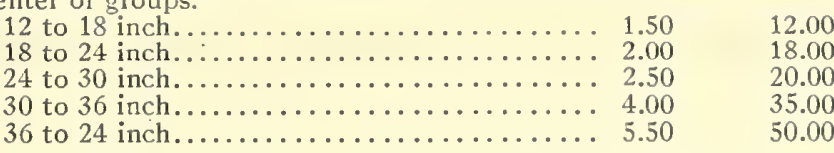

ABELIA GRANDIFLORA. A hardy, free blooming shrub with shiny, purplish evergreen leaves; bears profusion of clusters of tubular shaped flowers about one inch long, white inside, delicate pink out. Fragrant blooms last all summer. Very desirable.

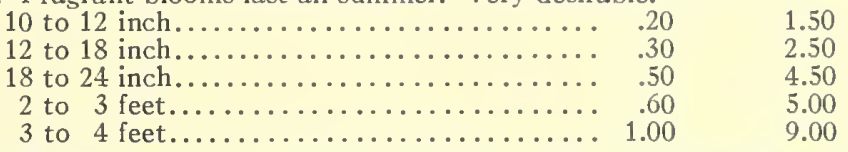

BOXWOOD, Buxus. Extensively used for hedges in formal gardens, and as specimen plants for lawn and landscape. They are justly pophlar, hardy evergreens. The leaves are small, round and glossy green; es a roundish bush that can be trimmed to any shape.

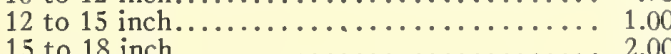

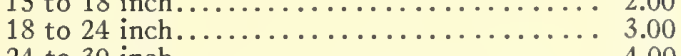

24 to 30 inch........................ 36 inch.........

EUONYMUS JAPONICUS, Evergreen Euonymus. Upright, hardy compact grower, attractive dark green, shiny foliage. Widely used for hedges, specimen planting, landscape massing, and for formal

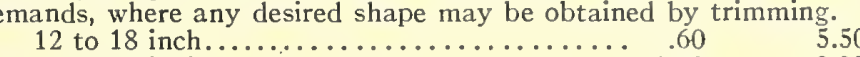

18 to 24 inch

$\begin{array}{rr}1.00 & 9.00 \\ 1.50 & 12.00\end{array}$

ILEX OPACA, American Holly. The Christmas evergreen tree. The large, glossy leaves and bright red berries make it a most attractive at planting time. Use a good leaf mold or rich woods-dirt when planting.

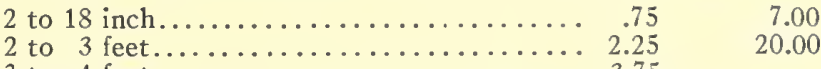

APANESE PRIVETT, Ligustrum. A handsome evergreen shrub with thick, dark, glossy green leaves. Small, creamy white blooms in well.

18 to 24 inch......

3 to 4 feet

NANDINA DONIESTICA. Beautiful little evergreen, which grows well in either sun or shade. The white flowers are produced in panicles and are followed by red berries. The new foliage is tinted with pink, and in winter becomes a beautiful bronze color. Each

15 to 18 inch.

2 to 3 feet

MAGNOLIA GRANDIFLORA, Southern Magnolia. This is the grandest of all our native evergreen trees; has broad shiny leaves, immense white, fragrant blossoms. Well known throughout the uth. Beautiful from small tree to maturity.

18 to 24 inch

2 to 3 feet.
3 to 4 feet.

4 to 6 feet.

All Evergreens offered in this list will be dug with ball of earth unless otherwisc instructed. All are strictly first class in BARGAINS.
J. L. MOCK. Very large full and fragrant; petals silvery, rose white inside, outside carmine pink. Continuous bloomer.

FRANCIS SCOTT KEY. Large, double flowers of rich crimson-red; a strong, sturdy grower and free bloomer.

FRANK $\mathbf{W}$. DUNLOP. Brilliant, deep rose pink; free flowering, very double, and highly scented.

HADLEY. Deep, rich, velvety crimson; well-formed buds on long stiff stems.

HANSA. A typically Rugosa, producing freely large double, reddish violet blooms.

WILLOWMERE. A handsome large rose of excellent form, super 
buds and blooms of richest pink, shining with a yellow glow, which seems to come from the heart of the flower. Resembles the Los Angeles. DUCHESS OF WELLINGTON. Long, large, tapering semi-double, saffron yellow buds, slowly opening to fragrant yellow flowers. WILIII R SIITH. Flowers are freely produced, creamy white WrLLIAM R. SMIII. Flowers are freely produced, creamy white with strong tints of pink and lilac; dependable rose for the North. MRS. B. R. CANT. New rose, exceedingly hardy, producing in profusion deep crimson-pink flowers, double, delightfully fragrant. DR. EUGENE E. MARLITT. Flowers large, double, a rich, bright crimson.

CLO'TILDE SOUPERT. Free bloomer, pink flowers.
CIIMBING ROSES-HARDY, FIELD-GROWN

Prices of Climbing Roses-2-year-old No. $140 \mathrm{c}$ each; $\$ 3.50$ per 10. DOROTHY PERKINS. Soft bluish pink, a favorite among pink climbers.

DR. HUEY. Deep crimson shaded maroon, semi-double, prolific bloomer.

GARDENIA. Rich yellow toning to cream. Early and prolific.

MARY WALLACE. Vivid pink, shaded salmon. Early bloomer, on long growth.

PAUL'S SCARLET CLIMBER. Brilliant scarlet blooms of lasting color

\section{PLANT-FOREST TREE SEEDLINGS FOR PROFIT, SHADE AND BEAUTY}

No farm should be without a grove of Forest Trees. The expense is very small, it pays well in shade and timber, and may mean a good estate for your children in years to come.

Your farm will always need fences. Your fences will always need posts. The Black or Yellow Locust grows the best of posts quickly.

Grow a Black Walnut Orchard on your farm. 'The trees will produce the finest, the most valuable timber, and at the same time yield quantities of the richest nuts, which are sold in abundance at good prices. When you want lumber for your buildings you will find nothing better than the Tulip (Yellow) Poplar. You perhaps have idle waste land on your farm that will grow a,few trees, which will make the land rich and yield you a profit at the same time.

Place your order now while the stock is plentiful, shipment to be made any time you are ready after October 20 th. We have this year larger assortment, better storage and packing sheds, and a strong desire to please you, and hope that you may let us supply your wants in this line.

AMERICAN BEECII, Fagus Americana.

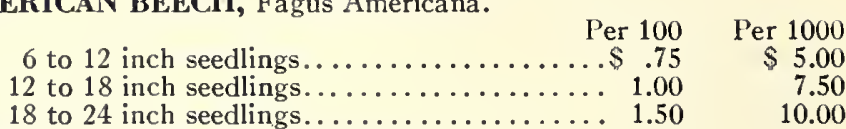

IERICAN SWEET CHESTNUT.

2 to 3 feet.................................

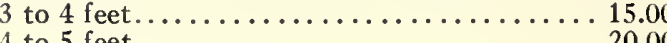

ASII (Green), Fraxinus Viridis.

6 to 12 inch..........................60

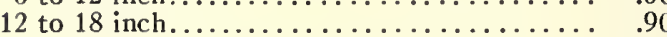

18 to 24 inch

4.00
7.00

10.00

SII (White), Fraxinus Americana.

6 to 12 inch........................ 60

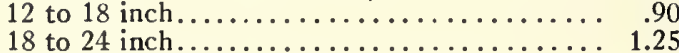

CATALPA SPECIOSA, Western Catalpa

12 to 18 inches......................... 90

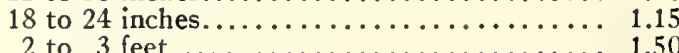

2 to 3 feet.......

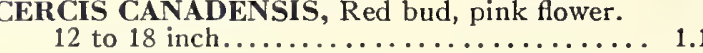

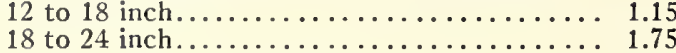

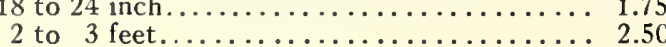

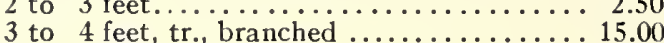

ELM (American White), Ulmus Americana.

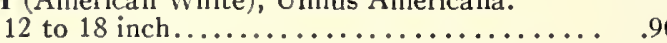

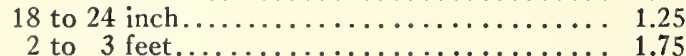

ILLIA AMERICANA, American Linden.

12 to 18 inch, seedlings ............... 2.50

18 to 24 inch, seedlings............... 3.50

RIODENDIRON TULIPIFERA, Tulip Tree.

12 to 18 inch............................... 1.15

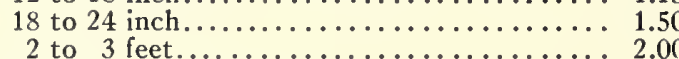

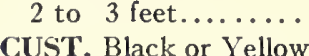

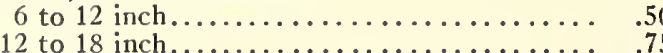

18 to 24 inch.....................................

2 to 24 inch.......................... 1.00

MAPLE, Soft or Silver.

12 to 18 inch, seedlings............... .75

18 to 24 inch, seedlings .75
1.00
4.00

7.00

10.00

6.00

8.00
10.00

8.00

8.00
12.00

18.00

6.00
9.00

9.00
12.00

15.00

20.00

35.00

8.00

10.50

16.00

3.50

5.00
7.50
10.00

5.00

8.00
Per 100 Per 1000

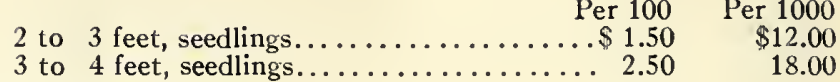
MAPLE, Hard or Sugar.

12 to 18 inch, seedlings............... $4.50 \quad 35.00$

18 to 24 inch, seedlings. ..................... 6.00

2 to 3 feet, seedlings.................... 6.00

IULBERRY, Russian.

6 to 12 inch, seedlings. . . . . . . . . . . . . . $50, \quad 3.75$

12 to 18 inch, seedlings...................... $1.00 \quad 7.50$

18 to 24 inch, seedlings................ $1.25 \quad 10.00$

OSA GE ORANGE

6 to 12 inch, seedlings................. .60 $\quad .60$

18 to 24 inch, seedlings.................. $.90 \quad 7.00$

WALNUT, Black.

6 to 12 inch, seedlings............... $1.50 \quad 12.50$

12 to 18 inch, seedlings................ $2.00 \quad 17.00$

18 to 24 inch, seedlings................ $3.00 \quad 25.00$

2 to 3 feet, seedlings................. 4.00

WALNUT, White.

12 to 18 inch, seedlings................. $1.50 \quad 12.50$

2 to 3 feet, seedlings........................ $3.00 \quad 3.00$

SWEET GUM.

12 to 18 inch, seedlings................ $2.50 \quad 18.00$

18 to 24 inch, seedlings................ 3.00

SYCAMORE,

6 to 12 inch, seedlings............... $1.50 \quad 10.00$

12 to 18 inch, seedlings.................... $2.00 \quad 15.00$

18 to 24 inch, seedlings.................... $3.00 \quad 20.00$

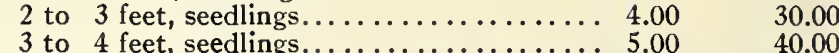

LONICERA HALLIANA, Hall's Japan Honeysuckle. Dark green, dense foliage, almost evergreen, with fragrant white flowers, changing to yellow. A good old dependable Honeysuckle. Grows rank under any conditions. These are being used in large quantities for reforestaany conditions. These are being used in large quantities for reforestawanted in quantity lots, write for special quotations.

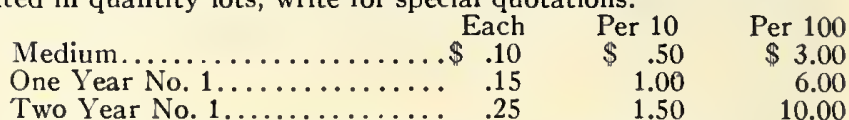

Two Year No. 1. $\begin{array}{llr}15 & 1.00 & 1.00\end{array}$

All the above stock offered are seedlings. If you want heavy, transplanted stock, refer to descriptive catalogue, or write for special prices. We guarantee all the seedlings to be healthy and strictly first-class
in all respects.

\section{BULBS FOR FALL PLANTING}

We have a large stock of Tulips, Hyacinths, Lilies, Crocusand other bulbs for Fall planting. Ask for special bulb folder, in colors, and see what your dollars will do for you at Boyd's.

\section{DISCOUNTS}

$10 \%$ DISCOUNT from list prices if cash order is received within ten days after receipt of this price list.

$3 \%$ DISCOUNT from list prices at any time when cash accompanies order.
Orders shipped C. O. D. if one-fourth cash accompanies order.

No discount on C. O. D. Orders.

BUY WISELY-TAKE ADVANTAGE OF THESE SPECIAL UISCOUNTS FOR CASII AND PROMPTNESS IN ORDERING.

Don't forget that all our items carried are not listed on this sheet. If you do not find what you want described here, drop us a line and we will be glad to send you our full descriptive catalogue, or give personal attention to any special item.

\section{BOYD NURSERY COMPANY}

